\title{
AUTHORISATION OF ABORTION FOR A "SERIOUS DANGER TO MENTAL HEALTH": WOULD THE PRACTICE STAND UP TO THE JUDICIAL TEST?
}

\author{
Amy Dixon*
}

In Right to Life New Zealand Inc v The Abortion Supervisory Committee, Miller J observed that, "there is reason to doubt the lawfulness of many abortions authorised by certifying consultants". This article questions this observation through an interpretation of "serious danger ... to ... mental health", the most commonly cited ground for authorisation of abortion. Is "mental health" limited to "absence of mental illness" or does it also include "mental wellbeing", which might allow for a more liberal practice? The narrow definition would accord with one objective of the abortion scheme to respect the rights of the unborn child. The wider definition would allow certifying consultants to freely exercise their medical judgement, a condition on which the abortion scheme is based. This article argues that the latter argument is potentially stronger, but its success rests on the willingness of the judiciary to engage in ambulatory statutory interpretation in the controversial context of abortion. This article concludes by noting that a finding in favour of the narrow definition of mental health still confers substantial flexibility on consultants in assessing danger of mental illness. Finally, this article recommends that Parliament intervene to make the law certain.

\section{INTRODUCTION}

Abortion in New Zealand is a crime unless two certifying consultants believe in good faith that the woman qualifies for an abortion under the exceptions in s 187A of the Crimes Act $1961 .^{1}$ Despite this, New Zealand has a comparable rate of abortion to that of jurisdictions in which women

* Submitted as part of the LLB(Hons) programme at Victoria University of Wellington. I would like to thank Claudia Geiringer for her superb guidance and support.

1 The statutory rules regulating abortion are found in ss 182-187A of the Crimes Act 1961, the Crimes Amendment Act 1977 and ss 10-46 of the Contraception, Sterilisation, and Abortion Act 1977. These provisions will collectively be referred to as the abortion legislation. 
have a guaranteed right to abortion. ${ }^{2}$ It would appear that the reason for this is the consultants' application of the exception which allows for abortion where the continuance of pregnancy would result in "serious danger ... to ... mental health" (the mental health exception). ${ }^{3}$ Ninety eight per cent of all abortions are authorised under this exception. ${ }^{4}$

These noteworthy statistics led Miller J, in the 2008 High Court decision of Right to Life New Zealand Inc $v$ The Abortion Supervisory Committee (Right to Life), to observe that: "There is reason to doubt the lawfulness of many abortions authorised by certifying consultants". ${ }^{5}$ His Honour doubted that so many women would be able to establish that continuance of pregnancy would result in a risk of a recognised diagnosis of mental illness, ${ }^{6}$ which he assumed is what would constitute the necessary "serious danger ... to ... mental health". ${ }^{7}$

Although the Court of Appeal has since ruled that Miller J's observations have "no lawful effect", the question of whether the consultants' approach to the mental health exception is lawful remains up in the air. ${ }^{8}$ A future finding of unlawfulness could significantly impact current abortion availability. Some doubt remains as to whether consultants are applying the law as liberally as Miller $\mathrm{J}$ assumed. If his Honour's doubts prove to be correct, however, current practice remains vulnerable to judicial determination of the scope of the mental health exception.

This article will test whether a court would uphold Miller J's assumption that "serious danger ... to ... mental health" must rest on a recognised diagnosis of mental illness. ${ }^{9}$ The main enquiry will be as to the meaning of "mental health": is "mental health" limited to the narrow definition of mental health, that is, "absence of mental illness", as Miller $\mathrm{J}$ assumed? Or does it include the wide definition of mental health, that is, "mental wellbeing", which might account for consultants' more liberal application?

The case for the narrow definition rests on the argument that it would uphold the objective of the abortion scheme to respect the rights of the unborn child. The main argument in favour of the wide definition is that it would accord with the scheme's concurrent aim to allow consultants to freely

2 Right to Life New Zealand Inc v The Abortion Supervisory Committee [2008] 2 NZLR 825 (HC) at [56]. Jurisdictions referred to include Canada and the United States.

3 Crimes Act, s 187A(1)(a).

$4 \quad$ Right to Life New Zealand Inc v The Abortion Supervisory Committee, above n 2, at [56].

5 At [56].

6 At [5].

7 At [125].

8 The Abortion Supervisory Committee v Right to Life New Zealand Inc [2011] NZCA 246, [2012] 1 NZLR 176 at [137].

9 At [125]. 
exercise their medical judgement, in light of growing recognition by the medical profession of the wide definition of mental health. This article suggests that the latter argument is potentially stronger, but its success will largely depend on the courts' willingness to engage in ambulatory interpretation in the controversial context of abortion law. Further, this article finds that a human rights analysis, despite raising some interesting questions, would not support the wide definition.

This article suggests that a finding in favour of the wide definition of mental health would mean that the meaning of the mental health exception could accord with practice. In the alternative, this article finds that if a court did adopt the narrow definition, consultants would still have substantial flexibility to consider all relevant factors in assessing whether continuance of pregnancy would result in a risk of mental illness, which should not be limited to "recognised" mental illness. Ultimately, this article suggests that Parliament should intervene to make the law certain.

\section{ABORTION LAW IN NEW ZEALAND}

To begin, it is necessary to lay down some background to the law regulating abortion in New Zealand. Under the Crimes Act 1961, it is illegal to "unlawfully" procure ${ }^{10}$ or supply the means of procuring ${ }^{11}$ an abortion or "miscarriage". ${ }^{12}$ Until 1977, the courts defined the meaning of "unlawfully" in these two sections. ${ }^{13}$ Shortly before the enactment of current abortion law in 1977, the Court of Appeal confirmed in $R v$ Woolnough that abortion would be lawful where there was a serious danger to the life, or physical or mental health of a woman. ${ }^{14}$

Amidst much societal debate around abortion, the Government established the Royal Commission of Inquiry into Contraception, Sterilisation and Abortion in $1975,{ }^{15}$ which reported in

10 Crimes Act, s 183.

11 Section 186. Sections 183 and 186 of the Crimes Act derive from ss 58 and 59 of the Offences Against the Person Act 1861 (UK) 24 \& 25 Vict c 100.

12 Miscarriage is defined in s 182A of the Crimes Act as "the destruction or death of an embryo or fetus after implantation" or "the premature expulsion or removal of an embryo or fetus after implantation, otherwise than for the purpose of inducing the birth of a fetus believed to be viable or removing a fetus that has died".

13 Nicola Peart "Prevention and Termination of Life before Birth" in PDG Skegg and Ron Paterson (eds) Medical Law in New Zealand (Thomson Brookers, Wellington, 2006) 473 at 484.

$14 R v$ Woolnough [1977] 2 NZLR 508 (CA). This case confirmed the exception outlined in $R v$ Bourne [1939] 1 KB 687 (Court of Criminal Appeal).

15 Right to Life New Zealand Inc v The Abortion Supervisory Committee, above n 2, at [9]; see also Abortion Services in New Zealand "A brief history of abortion laws in New Zealand" (2 May 2005) $<$ www.abortion.gen.nz>. 
1977. ${ }^{16}$ The Royal Commission's recommendations formed the basis for the enactment of the Contraception, Sterilisation and Abortion Act 1977 and the Crimes Amendment Act 1977. ${ }^{17}$

In accordance with these Acts, the grounds for abortion under 20 weeks' gestation ${ }^{18}$ are if: ${ }^{19}$

- continuance of the pregnancy would result in serious danger (not being danger normally attendant upon childbirth) to the life, or to the physical or mental health of the mother (this is the ground which includes the mental health exception); or

- $\quad$ there is a substantial risk of severe foetal abnormality; or

- $\quad$ the pregnancy is a result of incest or unlawful sex with a guardian; or

- $\quad$ the mother is severely mentally subnormal.

Though not grounds in themselves, sexual violation or extremes of age may be taken into account in determining danger to life or health. ${ }^{20}$

To obtain an abortion, a woman must first consult her doctor. ${ }^{21}$ If that doctor believes that one of the grounds for abortion may apply, he or she may refer the woman to two consultants. ${ }^{22}$ An abortion may not be performed unless two consultants issue a certificate of authorisation, ${ }^{23}$ after forming the opinion that one of the above grounds applies. ${ }^{24}$ Consultants are protected from civil or criminal liability if they make this decision in good faith. ${ }^{25}$

16 Royal Commission on Contraception Sterilisation and Abortion Contraception, Sterilisation and Abortion in New Zealand: Report of the Royal Commission of Inquiry (Government Printer, 1977).

17 On introducing the Bill, the Government said it encapsulated the Royal Commission's recommendations. The Government made slight amendments which do not significantly affect the issue in this article during the legislative process. See Margaret Sparrow Abortion Then \& Now: New Zealand Abortion Stories from 1940 to 1980 (Victoria University Press, Wellington, 2010) at 149.

18 Under s 187A(3) of the Crimes Act, after 20 weeks' gestation, abortion may only be authorised to save the life of the mother, or to prevent serious permanent injury to her physical or mental health.

19 Crimes Act, s 187A(1).

20 Section $187 \mathrm{~A}(2)$

21 Contraception, Sterilisation, and Abortion Act, s 32.

22 Ibid s 32. The woman's own doctor may also act as one of these certifying consultants.

23 Ibid s 29.

24 Ibid s 33.

25 Ibid s 40. Subsequent performance of an abortion is lawful under s 187(4) of the Crimes Act where a practitioner acts on the certificate issued by the consultants, unless the practitioner does not believe that the consultant had a good faith opinion that one of the grounds were satisfied. 
The Contraception, Sterilisation and Abortion Act also establishes the Abortion Supervisory Committee (ASC). ${ }^{26}$ The ASC has a number of statutory functions under that Act. ${ }^{27}$ These functions include general oversight of abortion law, ${ }^{28}$ ensuring consistent administration of the law, ${ }^{29}$ appointing and removing consultants, ${ }^{30}$ and reporting on the law's operation to Parliament. ${ }^{31}$

\section{RIGHT TO LIFE NEW ZEALAND INC V THE ABORTION SUPERVISORY COMMITTEE}

The operation of the ASC and the abortion legislation have recently come under the scrutiny of the High Court and the Court of Appeal in proceedings originally brought by Right to Life New Zealand Inc (Right to Life) for judicial review of the ASC. ${ }^{32}$ Right to Life's primary concern in those proceedings was that abortion in New Zealand is unlawfully available "on request". ${ }^{33}$ Right to Life attributed this situation to what it said was the failure of the ASC to ensure that consultants are properly applying the mental health exception. ${ }^{34}$

In the 2008 High Court decision of Right to Life, ${ }^{35}$ Miller J heard Right to Life's claim that the ASC was failing to exercise its statutory functions because it was not ensuring that the consultants were properly applying the grounds for abortion. ${ }^{36}$ The ASC argued in response that it had correctly refrained from reviewing consultants' authorisation decisions in line with the Court of Appeal

26 Contraception, Sterilisation, and Abortion Act, s 10. The Abortion Supervisory Committee (ASC) consists of three members, two of whom must be medical practitioners.

27 Section 14(1).

28 Section 14(1)(a).

29 Section 14(1)(i).

30 Section 30.

31 Section 14(1)(k).

32 Right to Life New Zealand Inc is a charitable society which aims to protect the rights of the unborn child; see Right to Life New Zealand "About/Contact Us" (2012) < www.righttolife.org.nz>.

33 Right to Life New Zealand Inc $v$ The Abortion Supervisory Committee, above n 2, at [4].

34 Ibid at [4].

35 At [35]; see Right to Life New Zealand Inc v The Abortion Supervisory Committee HC Wellington CIV2005-485-999, 31 March 2008 for the earlier procedural history.

36 At [37]. 
decision in Wall $v$ Livingston. ${ }^{37}$ In Wall $v$ Livingston, the Court of Appeal found that neither the Court nor the ASC could challenge the individual clinical judgements of consultants. ${ }^{38}$

In Right to Life, Miller J concluded that the ASC had misinterpreted its legislative powers and functions. ${ }^{39}$ His Honour found that the ASC had wrongly reasoned that Wall $v$ Livingston meant it could not review or scrutinise consultants' decisions at all. ${ }^{40}$ In his opinion, the decision in Wall $v$ Livingston did not prevent the ASC from reviewing consultants' authorisation decisions after the abortion had been carried out. ${ }^{41} \mathrm{He}$ found that the ASC should exercise its power to require consultants to keep proper records of, and report on, cases that they have considered. ${ }^{42}$ This would allow the ASC to fulfil its functions of overseeing and ensuring consistent application of the law, appointing and removing consultants, and of reporting to Parliament. ${ }^{43}$ To the extent necessary to perform these functions, he found that the ASC may form its own view of the lawfulness of the consultants' decisions. ${ }^{44}$

In the course of his decision, Miller J acknowledged Right to Life's concern by observing that there is "reason to doubt the lawfulness of many abortions authorised by certifying consultants". ${ }^{45}$ His Honour doubted that consultants were applying the mental health exception as Parliament had intended. ${ }^{46}$ He noted that New Zealand's abortion rate is comparable to that of jurisdictions where women have a guaranteed right of access to abortion, ${ }^{47}$ and that 99 per cent of all requests for abortion are approved. ${ }^{48} \mathrm{He}$ was suspicious of the application of the mental health exception in

37 At [41]; Wall v Livingston [1982] 1 NZLR 734 (HC). This case concerned an application for judicial review by a doctor of a decision by two certifying consultants to authorise an abortion for a teenage girl. The doctor believed there were no grounds under s 187A of the Crimes Act to authorise the abortion.

38 Wall $v$ Livingston, ibid.

39 Right to Life New Zealand Inc v The Abortion Supervisory Committee, above n 2, at [5].

40 At [5].

41 At [66]. At [123], Miller J draws a distinction between review before the abortion is carried out, and "afterthe-fact" review.

42 At [132]. Miller $\mathrm{J}$ found this power was available under s 36 of the Contraception, Sterilisation, and Abortion Act.

43 At [5].

44 Ibid.

45 Ibid.

46 At [56].

47 Ibid.

48 At [47]. Statistics showing the comparison of approved to declined requests are not included in the ASC's annual reports to Parliament. The evidence supporting the approval rate of 99 per cent reported by Miller J 
particular because of the fact that 98 per cent of approvals are made under that ground. ${ }^{49}$ Miller $\mathrm{J}$ found further support for his observation in some of the ASC's comments in its annual reports to Parliament. ${ }^{50}$ For example, in 2000 the ASC noted that the abortion legislation's procedures "are not being followed as the law intended". ${ }^{51}$ In 2005, it stated that "the wording has come to have a de facto liberal interpretation". 52

Underlying Miller J's observation was the assumption that authorisation under "serious danger ... to ... mental health" could only be lawful if it rested on a real risk of a recognised diagnosis of mental illness. ${ }^{53}$ His Honour doubted that so many women would be able to establish that continuance of pregnancy would pose such a risk. ${ }^{54}$ Though he made no final conclusion, Miller J suggested, in line with Right to Life's concern, that New Zealand unlawfully has abortion "on request". 55

On appeal, the Court of Appeal by a majority overturned Miller J's finding that the ASC could review consultants' authorisations after the fact. ${ }^{56}$ The majority found that after-the-fact review of consultants' authorisations would be inconsistent with Wall $v$ Livingston. ${ }^{57}$ The majority highlighted that the Court in Wall v Livingston emphasised the general nature of the ASC's oversight function and found that these functions should be completely removed from the medical decisions of consultants. ${ }^{58}$ The majority of the Court of Appeal in Right to Life thus concluded that the functions and powers of the ASC did not extend to after-the-fact review. ${ }^{59}$

in Right to Life New Zealand was based on data collected on a one-off basis. Miller J referred to data showing approval rates of the 20 highest fee earning consultants. This was provided in response to a request in 2005. He also referred to statistics showing the rate of approvals in the Christchurch region. This was collected manually, specifically for the case. (Obtained under Official Information Act 1982 Request to the Abortion Supervisory Committee).

49 At [56].

50 Ibid.

51 Report of the Abortion Supervisory Committee (2000) cited in Right to Life New Zealand Inc v The Abortion Supervisory Committee, ibid at [51].

52 Report of the Abortion Supervisory Committee (2005) cited in Right to Life New Zealand Inc v The Abortion Supervisory Committee, ibid at [50].

53 At [125].

54 At [56] and [125].

55 At [56].

56 The Abortion Supervisory Committee v Right to Life New Zealand Inc, above n 8, at [109].

57 At [109].

58 At [98].

59 At [100]. 
Because of their finding that the ASC does not have the power to review decisions of certifying consultants, the majority of the Court of Appeal also found that it was inappropriate for Miller $\mathrm{J}$ to have made observations about the lawfulness of consultants' authorisations. They concluded that his comments have "no lawful effect". ${ }^{60}$

In contrast to the majority's decision, Arnold J, dissenting, expressed approval of Miller J's findings in the High Court. Arnold J agreed that the ASC's statutory powers and functions allowed for after-the-fact review, ${ }^{61}$ and that such review would not be inconsistent with Wall $v$ Livingston. ${ }^{62}$ His Honour stressed that the ASC would only need to review the decisions to the extent necessary to fulfil its functions of evaluating the operation of the abortion legislation and appointing or removing consultants. ${ }^{63} \mathrm{He}$ also agreed with Miller $\mathrm{J}$ that the statistical data on abortion rates "gives ground for concern" that the consultants are not applying the mental health exception as Parliament intended. ${ }^{64}$

\section{IS THE PRACTICE STILL VULNERABLE TO MILLER J'S DOUBTS?}

Although the Court of Appeal ruled that Miller J's observations have "no lawful effect", ${ }^{65}$ the issue of whether consultants are misapplying the mental health exception has not yet been laid to rest. A conclusive finding that current practice is unlawful could significantly impact the availability of abortion. The most significant factor in Miller J's observations which poses a threat to current practice is his assumption that authorisation under "serious danger ... to ... mental health" must rest on a real risk of a recognised diagnosis of mental illness. A court could affect current practice if interpretation of the mental health exception arises, and the court confirms Miller J's interpretation.

The interpretation of the mental health exception could yet arise in the courts. Most pertinently, the Supreme Court has granted Right to Life leave to appeal the decision in Right to Life. ${ }^{66}$ The Supreme Court has given itself the option to consider the evidential foundations for Miller J's observation that there is reason to doubt the lawfulness of consultants' authorisations. It may be necessary for the Court to conclusively determine the correct interpretation of the mental health exception in that case.

60 At [137].

61 At [183].

62 At [188]. Arnold J reasoned that the Court in Wall v Livingston would have considered that the ASC's general oversight function includes after-the-fact review.

63 At [179].

64 At [197].

65 At [137].

66 Right to Life New Zealand Inc v The Abortion Supervisory Committee [2011] NZSC 97. 
The opportunity for interpretation by the courts might be more likely to arise if the Supreme Court finds that the ASC has the power to review the consultants' authorisations. The ASC might then state a case for the High Court to determine the lawful meaning of the mental health exception. ${ }^{67}$ Further, the issue could arise in judicial review of a decision to revoke a consultant's appointment, although it is unclear whether a consultant would actually be able to bring judicial review of such a decision. ${ }^{68}$

On the law as it currently stands, all possible avenues of review of consultants' authorisations involve establishing that the authorisation was made in bad faith. These avenues include a bad faith review by the courts or by the ASC, ${ }^{69}$ the criminal law or a complaint to the Health and Disability Commissioner. ${ }^{70}$ Interpretation of the mental health exception could still, however, arise in these forums. ${ }^{71}$ Bad faith involves the commission of an error with knowledge that the error is being committed. ${ }^{72}$ Interpretation of the exception may first be relevant to establishing commission of an error. Secondly, although the factual basis or the reasonableness of the decision is not a consideration in establishing knowledge, it may inform whether the belief was honestly held. ${ }^{73}$

There are, however, two reasons why a conclusive determination of the correct meaning of the mental health exception might not affect current practice. First, there is some evidential doubt that the consultants are in fact applying the law as liberally as Miller J suspected. The statistics and the ASC's comments reviewed by Miller $\mathrm{J}$ do not conclusively indicate that the consultants are applying the mental health exception liberally. First, risk of mental illness may be more prevalent among women seeking abortion than among pregnant women generally. ${ }^{74}$ Second, the high rates of approval per consultant may be skewed because the number of declined requests does not include

67 Contraception, Sterilisation and Abortion Act, s 28

68 Under s 30(7) of the Contraception, Sterilisation and Abortion Act, the ASC may at any time, at its discretion, revoke a consultant's appointment. There is no provision for appeal of this decision. For discussion of s 30(7) see The Abortion Supervisory Committee v Right to Life New Zealand Inc, above n 8, at [29].

69 The Abortion Supervisory Committee v Right to Life New Zealand Inc, above n 8, confirming the earlier decision of Wall $v$ Livingston, above $\mathrm{n} 37$.

70 A complaint may be brought for breach of the Code of Health and Disability Services Consumers' Rights (found in Health and Disability Commissioner (Code of Health and Disability Services Consumers' Rights) Regulations 1996) under the Health and Disability Commissioner Act 1994, s 31. Under the code, a woman has the right to treatment which adheres to legal standards.

71 Contraception, Sterilisation and Abortion Act, s 40.

72 GD Taylor Judicial Review: A New Zealand Perspective (2nd ed, LexisNexis, Wellington, 2010) at 70.

73 Nicola Peart "Prevention and Termination of Life before Birth", above n 13, at 486.

74 Miller $\mathrm{J}$ acknowledged this possibility in Right to Life New Zealand Inc $v$ The Abortion Supervisory Committee, above n 2, at [54]. 
women who consider abortion, but do not get to the stage of referral to the first consultant. ${ }^{75}$ Before referral, a woman first consults her own doctor who decides whether the criteria may apply. ${ }^{76}$ The woman is then offered counselling before being referred to the first consultant. ${ }^{77}$ Inevitably, the doctor may sometimes decide a woman does not meet the criteria for referral or a woman might herself decide not to proceed prior to referral.

Further, the ASC's comments that consultants are liberally applying the law are not necessarily indicative of the true situation. The comments appeared in brief annual reports which cover a range of issues. ${ }^{78}$ The comments may also have been overstated because they were made at the same time that the ASC recommended that the law be liberalised. ${ }^{79}$ The comments may thus simply reflect the membership at the time. The current committee, appointed in $2007^{80}$ has not made such comments in its reports. ${ }^{81}$ Thus, these factors indicate that there is a real possibility that there is no issue because consultants are not applying the law as liberally as Miller J would suggest.

The second reason that the consultants' approach might yet be unaffected by a conclusive determination of the meaning of the mental health exception is that even if consultants are taking a liberal approach, the courts may find that the mental health exception is open to a wider interpretation than Miller J assumed. Thus, the question which forms the basis for the remainder of the discussion in this article is: would the courts find that "serious danger ... to ... mental health" is limited to a real risk of a recognised diagnosis of mental illness, as Miller $\mathrm{J}$ assumed, or, can it be interpreted more widely?

\section{INTERPRETATION OF "SERIOUS DANGER ... TO ... MENTAL HEALTH"}

The meaning of the phrase "serious danger ... to ... mental health" must ultimately be considered as a whole. The most contentious issue, however, is the meaning of "mental health". More specifically, should it be read narrowly to mean 'absence of illness' or more widely to mean

75 Ibid. Statistics showing numbers of approvals and denials per consultant in Right to Life New Zealand Inc $v$ The Abortion Supervisory Committee do not differentiate between the first or second certifying consultant. Both first and second certifying consultants are required to complete a form indicating their decision after consultation with a woman seeking abortion. These forms are then provided to the Ministry of Justice. (Obtained under Official Information Act 1982 Request to the Abortion Supervisory Committee).

Contraception, Sterilisation, and Abortion Act, s 32.

77 Report of the Abortion Supervisory Committee (2010) at 18.

78 The Abortion Supervisory Committee v Right to Life New Zealand Inc, above n 8, at [196].

79 Ibid at [196].

80 Report of the Abortion Supervisory Committee (2007) at 4.

81 From 2006-2010 there have been no such comments in the Abortion Supervisory Committee's annual reports to Parliament. 
'mental wellbeing'? These two possible conceptions of "mental health" will be outlined, and arguments in favour of a court adopting each will be considered. Following this, the interpretation of the whole phrase "serious danger ... to ... mental health" will be considered in light of the definition of "mental health".

But first, before embarking on interpretation, it is necessary to outline the tools that will be used. The overall task in interpreting the mental health exception, in terms of s 5(1) of the Interpretation Act 1999, is to ascertain its meaning from its text in light of its purpose. ${ }^{82}$ While the wording is the most important element in interpretation, it must be given its most natural meaning in light of its context and its purpose. ${ }^{83}$

"Purpose" is a flexible concept that essentially gives name to the task of reading the words of the Act in their whole context. ${ }^{84}$ Purpose might include, but is certainly not limited to, an inquiry into Parliament's subjective intention, or that which the legislators had in mind at the time of enactment. ${ }^{85}$ Beyond the end that Parliament aims to achieve, ${ }^{86}$ purpose can also mean the theme of the legislation. ${ }^{87}$ Inquiry into purpose should involve consideration of multiple factors including the language of the Act, the wider scheme of the Act, the drafting history and the Act's wider context. ${ }^{88}$

A wide range of factors will be considered in the interpretation of the abortion legislation. Beyond the abortion legislation itself, the Royal Commission report will be used to inform the wider context of the phrase and the abortion legislation. ${ }^{89}$ Rather than treating the report as a conclusive indication of the legislation's meaning, the report may be used as confirmation of the meaning ascertained from the text in light of its purpose. ${ }^{90}$ Before these tools are used to determine the meaning of "mental health", it is first necessary to set out the possible meanings of mental health.

82 Interpretation Act 1999, s 5(1).

83 J Burrows and R Carter Statute Law in New Zealand (4th ed, LexisNexis, Wellington, 2009) at 201.

84 Claudia Geiringer "Shaping the Interpretation of Statutes: Where Are We Now in the Section 6 Debate" in Using the Bill of Rights in Civil and Criminal Litigation (Continuing Legal Education New Zealand Law Society, Wellington, 2008) 1 at 13.

85 J Burrows and R Carter Statute Law in New Zealand, above n 83, at 184.

86 Ibid at 220 .

87 Ibid at 219.

88 Claudia Geiringer "Shaping the Interpretation of Statutes: Where Are We Now in the Section 6 Debate", above $n 84$.

89 As was accepted in both The Abortion Supervisory Committee v Right to Life New Zealand Inc, above n 8, at [5] and Right to Life New Zealand Inc v The Abortion Supervisory Committee, above n 2, at [10].

$90 \quad R v$ Aylwin [2008] NZCA 154, (2008) 24 CRNZ 87 at [58] per Glazebrook J. 


\section{A The Two Alternative Definitions of Mental Health}

Miller J in Right to Life assumed that "mental health" is about mental illness. ${ }^{91}$ Contrary to this assumption, there are broadly two possible conceptions of mental health which might apply to the mental health exception.

The negative definition of health, which Miller $\mathrm{J}$ apparently preferred, is the absence of illness. ${ }^{92}$ This definition arises out of a pathogenic approach to health, which concerns treatment and prevention of disease. ${ }^{93}$ According to this conception, "mental health" means the absence of mental illness. Thus "mental health" is found at one end of a continuum, and mental illness is at the other. ${ }^{94}$

There is, however, a competing, positive definition of health, which is about wellbeing. This definition is used widely in the growing field of health promotion, which focuses on facilitating health as opposed to treating illness. ${ }^{95}$ The classic positive definition of health is the World Health Organisation (WHO) definition, which defines health as "a state of complete physical, mental and social wellbeing and not merely the absence of disease or infirmity". ${ }^{96}$ The WHO defines mental health as "a state of wellbeing in which the individual realises his or her own abilities, can cope with the normal stresses of life, can work productively and fruitfully, and is able to make a contribution to his or her community". 97

Positive mental health consists of complete emotional, psychological and social wellbeing. ${ }^{98}$ It includes protective factors which preserve one's wellbeing. These include psychological and emotional capacities, social support, and educational and financial capacities. ${ }^{99}$ According to Corey

91 Right to Life New Zealand Inc v The Abortion Supervisory Committee, above n 2.

92 Corey LM Keyes "Promoting and Protecting Mental Health as Flourishing: A Complementary Strategy for Improving National Mental Health" (2007) 62 American Psychologist 95 at 96.

93 Ibid at 96.

94 Ibid.

95 World Health Organisation Promoting Mental Health: Concepts, Emerging Evidence, Practice: Summary Report (Geneva, 2004) at 16. This is a global movement which is supported by the World Health Organisation, beginning with the Ottawa Charter for Health Promotion (1986).

96 Constitution of the World Health Organisation 14 UNTS 185 (signed 22 July 1946, entered into force 7 April 1948), Preamble.

97 World Health Organisation Strengthening Mental Health Promotion (Geneva, 2001).

98 Corey LM Keyes "Promoting and Protecting Mental Health as Flourishing: A Complementary Strategy for Improving National Mental Health", above n 92, at 98.

99 Anne Shaffer and Tuppett Yates "Risk Factors and Protective Factors in Clinical Practice" in Michael T Compton (ed) Clinical Manual of Prevention in Mental Health (American Psychiatric Publisher, Washington DC, 2010) 29 at 34. 
Keyes, positive mental health is much more than the opposite of mental illness. ${ }^{100}$ It is a completely different concept. ${ }^{101}$ Keyes labels positive mental health as "flourishing", a state which he argues can co-occur with mental illness. ${ }^{102}$

The threshold for obtaining authorisation under "serious danger ... to ... mental health" would vary according to the definition adopted. If "mental health" were defined narrowly, a woman would need to show danger of mental illness to obtain authorisation under the mental health exception. This may be narrower than consultants' current approach. A finding in favour of this definition might therefore upset current practice. In contrast, if "mental health" were defined positively, this would allow a more flexible approach of finding danger to mental wellbeing. A finding in favour of this definition would provide better protection of current practice.

Miller J's observations provide no real support for a determination as to which of these definitions applies to the mental health exception. His Honour did not conduct a reasoned analysis of the abortion legislation before suggesting that authorisation should rest on recognised diagnoses of mental illness. ${ }^{103}$ In making this suggestion, Miller $\mathrm{J}$ was most likely partially influenced by the fact that the ASC has, in the past, advised consultants to use recognised diagnoses when authorising abortion under the mental health exception. ${ }^{104}$ In doing this, the ASC may have, however, been wrong or simply have been acting cautiously. As indicated above, the ASC's interpretation of the law may simply reflect its membership at the time. ${ }^{105}$ It is therefore necessary to delve into full interpretation of the mental health exception, starting with arguments which support Miller J's assumption that the narrow definition applies.

\section{B Arguments for the Narrow Definition of Mental Health}

The main argument in favour of the narrow definition is that adopting the narrow definition would better uphold a key purpose of the abortion legislation, which is to ensure that the authorisation regime has regard to the rights of the unborn child and therefore should prevent abortion 'on demand'. The narrow definition supports this purpose because it sets a higher threshold for obtaining abortion.

100 Corey LM Keyes "Promoting and Protecting Mental Health as Flourishing: A Complementary Strategy for Improving National Mental Health", above n 92, at 100.

101 Ibid.

102 Ibid.

103 Right to Life New Zealand Inc v The Abortion Supervisory Committee, above n 2, at [125].

104 Ibid at [57].

105 See Part IV of this article. 
A number of elements of the abortion legislation illustrate this purpose. The Contraception, Sterilisation and Abortion Act's long title states that it is "to provide for the circumstances and procedures under which abortions may be authorised after having full regard to the rights of the unborn child". ${ }^{106}$ This purpose is also evident in the procedure for appointing consultants. That Act precludes the appointment of consultants whose assessment will be coloured by views that are deemed to be "incompatible with the tenor of [the] Act". ${ }^{107}$ The Act states that one such view is that whether abortion is appropriate is "entirely a matter for the woman and a doctor to decide". ${ }^{08}$ Further, the very fact that the abortion legislation sets out a specific set of grounds for abortion ${ }^{109}$ strongly suggests that it does not intend to make abortion available "on demand". ${ }^{110}$

The context of the phrase "mental health" within the legislation would also support the narrow definition of mental health. "Mental health" is found in the phrase "serious danger ... to the life, or to the physical or mental health of the woman or girl". ${ }^{111}$ The history of this phrase supports the narrow definition. In $R v$ Bourne, the case which first proposed this wording, the Court widened the original test of preservation of the life of the woman to include dangers to both physical and mental health because the Court was of the opinion that these dangers would also threaten life. ${ }^{112}$ The Court in that case equated serious danger to mental health with causing the woman to become a "mental wreck". ${ }^{113}$ Second, the section which includes the mental health exception also lists two factors which consultants may take into account when deciding whether a "serious danger" exists. These are either that pregnancy is a result of sexual violation or that the woman is at the beginning or end of her child-bearing years. ${ }^{114}$ Notably, social and economic factors, which would be key factors in assessing danger to wellbeing, are not included in this list of factors to be taken into account. Though inconclusive, together this contextual evidence tends to support the narrow definition.

106 Contraception, Sterilisation, and Abortion Act. "Rights" do not include a legal right life as confirmed in both Right to Life New Zealand Inc v The Abortion Supervisory Committee, above n 2, and The Abortion Supervisory Committee v Right to Life New Zealand Inc, above n 8.

107 Section 30(5).

108 Section 30(5)(b).

109 Crimes Act, s 187A.

110 Ian Bassett "Liability of Health Professionals for a Breach of the Abortion Law in New Zealand" (2001) 9 Journal of Law \& Medicine 115.

111 Crimes Act, s 187A. See Part II of this article.

$112 R$ v Bourne, above n 14, at 692.

113 At 693-694.

114 Crimes Act, s 187A(2). 
The Royal Commission report provides strong confirmation of these arguments in favour of the narrow definition. The report suggests that preventing abortion 'on demand' is a key purpose of the legislation. The report stated that it is wrong to terminate unborn life "for reasons of social convenience". ${ }^{115}$ Preventing abortion 'on demand' was the key consideration for the Commission in determining the appropriate grounds for abortion. ${ }^{116}$ For this reason, it recommended inclusion of the words "not being danger normally attendant on childbirth" (included after "serious danger"). ${ }^{117}$ In the Commission's view, abortion would not be justified by "psychological stress which was relatively short in duration or of relatively mild intensity". ${ }^{118}$ For the same reason, the Commission chose not to recommend that socio-economic issues be a ground for abortion. ${ }^{119}$

The report also provides specific support for the suggestion that the legislation was drafted with the narrow definition in mind. The report states that health should be defined as "a condition of physical and mental soundness". ${ }^{120}$ The Commission could find "no real justification" for adopting the WHO definition of health. ${ }^{121}$ The Commission was again concerned that adopting this definition might lead to abortion 'on demand'. ${ }^{122}$

As illustrated, there is strong support within the legislation, with confirmation from the Royal Commission report for Miller J's assumption that "mental health" should be narrowly defined. The narrow definition corresponds with the purpose of having regard to the unborn child in authorising abortion. There is, however, also support for an argument against Miller J's assumption, in favour of finding that "mental health" can be defined more widely, which would allow for a more liberal interpretation by consultants.

\section{Arguments in Favour of the Wide Definition of Mental Health}

There are two contextual elements of the abortion legislation which may support the wide definition. The first is that allowing for the wide definition of "mental health" would be consistent with a concurrent purpose of the legislation. This second purpose of the abortion legislation is that

115 Royal Commission on Contraception Sterilisation and Abortion Contraception, Sterilisation and Abortion in New Zealand: Report of the Royal Commission of Inquiry, above n 16, at 200.

116 Ibid.

117 See Part II of this article for the wording in its context.

118 Royal Commission on Contraception Sterilisation and Abortion Contraception, Sterilisation and Abortion in New Zealand: Report of the Royal Commission of Inquiry, above n 16, at 270.

119 At 272 .

120 At 270

121 See in this article Part V, heading A.

122 Royal Commission on Contraception Sterilisation and Abortion Contraception, Sterilisation and Abortion in New Zealand: Report of the Royal Commission of Inquiry, above n 16, at 204. 
consultants must be free to exercise their medical judgement in making an assessment of an abortion application. Any developments in the conception of "mental health" should therefore be able to be considered as part of a consultant's professional judgement. The second element which may support the wide definition is that the legislation should be read in conjunction with the New Zealand Bill of Rights Act $1990^{123}$ and with the common law presumption of consistency with international law. ${ }^{124}$

\section{Leaving interpretation of "mental health" to medical judgement}

The Royal Commission's concern for protecting the rights of the unborn child came against the backdrop of the more fundamental decision to place the authorisation of abortion wholly in the hands of the medical profession. At the time that the Royal Commission recommended that the narrow definition be adopted, it did not appear to foresee that its aim of protecting the rights of the unborn child might come to conflict with its concurrent proposal to give consultants the discretion to make medical decisions. It did not appear to foresee that its proposed narrow definition of mental health might one day conflict with modern medical judgement. Although it did not expressly address the issue, the Commission arguably assumed that the narrow definition would accord with contemporary medical judgement, thus, this conflict would not arise. Today, however, there is an argument that allowing for the wide definition of mental health would be consistent with the desire of the legislation to give consultants the flexibility to exercise their medical judgement.

For this argument to prevail there must first be evidence that the notion that consultants should be free to exercise their medical judgement is a key purpose of the abortion legislation. Second, conceptions of mental health must have developed in such a way that to restrict "mental health" to its narrow definition would conflict with this purpose. Third, the phrase "mental health" within the legislation itself must be flexible enough to encompass the wider definition. And finally, this argument must be reconciled with the clear design of the legislation to give regard to the rights of the unborn child.

Turning to the first of these issues, the legislation itself, supported by case law, provides clear evidence that a key purpose of the legislation is that consultants must be free to exercise their medical judgement. Keeping in mind the earlier discussion on statutory interpretation, it is helpful to repeat that "purpose" may come in varying forms. While the purpose of protecting the rights of the unborn child comes more in the form of an aim or intention, ensuring that the consultants are free to exercise medical judgement is more a subtle theme of the abortion scheme which is essential to its proper function.

The abortion legislation clearly sets up a scheme which relies on the consultants' judgement. The legislation provides little in the way of guidance in applying the grounds for abortion. The grounds,

123 Section 6.

124 See for example Zaoui v Attorney-General (No 2) [2005] NZSC 38, [2006] 1 NZLR 289. 
including "serious danger ... to ... mental health", are set out in general terms without more specific indication of the conditions that would satisfy the criteria. In this the legislation recognises that the law should not interfere with what is essentially a medical judgement. As well as not restricting discretion, the legislation also protects consultants from any criminal or civil liability where authorisations are made in good faith. ${ }^{125}$ This ensures that consultants can exercise their free judgement without fear of repercussions.

The courts have consistently recognised that the legislation envisages authorisation as a medical decision and accordingly demands a degree of deference. The main reason behind the finding that authorisation decisions should not be open to review is that consultants should be free to exercise their judgement without fear of having their decisions substituted. In Wall v Livingston Woodhouse $\mathrm{P}$, in concluding that neither the courts nor the ASC can review individual consultants' decisions, noted that authorisation depended on a "medical assessment pure and simple". ${ }^{126}$ He noted that "adverse medical implications" might arise if decisions were reviewable. ${ }^{127}$ Miller J in Right to Life also recognised that because authorisation decisions are medical, ${ }^{128}$ there should be "room for the exercise of judgement". ${ }^{129}$ The medical nature of authorisation was also a key reason in the Court of Appeal's finding that the ASC cannot review consultants' decisions at all. ${ }^{130}$

To assess whether this purpose is affected by the interpretation of the mental health exception, it is important to look at the underlying justification for allowing flexibility in medical judgement. The justification for this is that this is essential to preserving the integrity of the doctor-patient relationship. Aside from the obvious concern that patients may not receive the best treatment if doctors cannot freely exercise their judgement, the law can create an ethical conflict for doctors if it requires them to act according to law which conflicts with their own medical judgement. To doctors, exercising medical judgement is just as important, if not more important, than the law. As Thomas Faunce argues, medical professionals consider relevant legal principles only after having first engaged their professional conscience. ${ }^{131}$ They interpret the law by trying to fit it into their

125 Contraception, Sterilisation, and Abortion Act, s 40.

126 Wall v Livingston, above $\mathrm{n} 37$, at 739.

127 At 739.

128 Right to Life New Zealand Inc v The Abortion Supervisory Committee New Zealand, above n 2, at [18].

129 At [125].

130 The Abortion Supervisory Committee v Right to Life New Zealand Inc, above n 8, at [98].

131 Thomas Faunce "Health Legislation and International Human Rights" in Suzanne Corcoran and Stephen Bottomley (eds) Interpreting Statutes (Federation Press, Annadale (NSW), 2005) 299 at 315. 
"community of principle" which includes medical ethics, health law and other values found in international human rights. ${ }^{132}$

A key principle in medical ethics is the principle of beneficence, which requires doctors always to act in their patient's best interests, which includes using best medical judgement. ${ }^{133}$ In the New Zealand context, this notion can be seen in the New Zealand Medical Association's principles including those of prioritising patient well-being, striving to give the best possible advice and treatment and honouring the profession in a way to best serve the patient's interests. ${ }^{134}$ In accordance with the principle of beneficence, in the context of abortion authorisation, a consultant aims to use his or her most up-to-date medical knowledge to assess whether there is a "serious danger ... to ... mental health". If his or her knowledge does not accord with the law, an ethical conflict will arise which may threaten the stability of the abortion scheme.

Thus, the second issue to be resolved is whether such a conflict would in fact arise today when consultants are applying the mental health exception. When the abortion legislation was initially drafted, it was foreseen that flexibility in medical judgement would only be necessary around assessment of "serious danger". The Royal Commission expected that there would be some variation in the consultants' assessment of the degree of danger posed by pregnancy. ${ }^{135}$ At the same time, the Commission expressed disapproval of the wide definition of mental health without concern that this would have an adverse effect on medical judgement either at the time or in the future. ${ }^{136}$

Today, however, the conception of mental health has developed to the point that this could create a conflict for consultants. There is no information available on exactly how consultants view "mental health" in their everyday practice. ${ }^{137}$ What is clear, however, is that since 1977 , the wide definition of health has become significantly more prominent within the context in which consultants work. Consultants are medical practitioners, ${ }^{138}$ many of whom also work as general practitioners in the primary healthcare system. ${ }^{139}$

132 Ibid at 315

133 Jonathan Herring Medical Law and Ethics (Oxford University Press, Oxford, 2008) at 24

134 New Zealand Medical Association Code of Ethics: For the New Zealand Medical Profession (Wellington, 2008) at 5.

135 Royal Commission on Contraception Sterilisation and Abortion Contraception, Sterilisation and Abortion in New Zealand: Report of the Royal Commission of Inquiry, above n 16, at 285.

136 At 270

137 As far as the author is aware.

138 Under s 30 of the Contraception, Sterilisation, and Abortion Act, certifying consultants are medical practitioners, of which half must be practising obstetricians or gynaecologists.

139 See Abortion Services in New Zealand "Certifying Consultants" (29 January 2012) <www.abortion.gen.nz> for a relatively recent list of certifying consultants and their site of practice. 
The wide definition of health has become increasingly relevant in the New Zealand primary health system with the growth of the health promotion field since the 1980s. ${ }^{140}$ More recently, the Government now expects primary healthcare to engage more in mental health promotion. ${ }^{141}$ The Ministry of Health's most recent mental health plan emphasises that the health system must expand its focus to the wellbeing of all New Zealanders and emphasises the need to address protective factors as well as risk factors for mental health. ${ }^{142}$

The wide definition of mental health is also becoming more important in addressing mental health issues. General practitioners play a key role in mental healthcare as the first port of call for those with such issues. ${ }^{143}$ There is growing recognition in mental healthcare literature of the "recovery model" of care, ${ }^{144}$ which in accordance with the wide definition of mental health, focuses on restoring a patient's subjective wellbeing and self-worth as opposed to simply treating illness. ${ }^{145}$ The use of this model of mental healthcare in New Zealand is growing. ${ }^{146}$ It is likely that these changes in environment would at least affect some consultants' views of mental health. Consequently, an ethical conflict might arise out of the clash between the consultant's knowledge and what the law demands if "mental health" were to be restricted to its narrow definition.

Despite this, the legislative phrase "mental health" must yet be legally capable of accommodating this updated meaning. Changed circumstances, such as these developments in the accepted definition of "mental health", can sometimes be accommodated through the ambulatory approach to statutory interpretation. In New Zealand, this approach is enshrined in the Interpretation Act 1999, which states that "enactments apply to circumstances as they arise". ${ }^{147}$ Accordingly,

140 John Smith "Strategies for Strengthening the Health Promotion Workforce An Academic's Perspective" (2006) Health Promotion Forum of New Zealand <www.hauora.co.nz>.

141 Ministry of Health Primary Health Organisations: Service Development Toolkit for Mental Health Services in Primary Health Care (Ministry of Health, Wellington, 2004) at 23.

142 Ministry of Health Te Tāhuhu - Improving Mental Health 2005-2015: The Second Mental Health and Addiction Plan (Ministry of Health, Wellington, 2005) at 8.

143 Anthony O'Brien, Fiona Moir and Katey Thom "The Provision of Mental Health Care by Primary Health Organisations in the Northern Region: Barriers and Enablers" (2009) 1 J Primary Health Care 120 at 120.

144 Lola Ianovski "Should Recovery Practices Within Mental Health Services Be Monitored? If so, How Can Organisation Recovery Orientation be Measured? A Qualitative Inquiry" (MHSc Dissertation, Auckland University of Technology, 2009) at 2.

145 Jim Campbell, Theo Stickley and Sarah Bonney "Recovery as a Framework for Care Planning" in Angela Hall, Mike Wren, and Stephan Kirby (eds) Care Planning in Mental Health: Promoting Recovery (Blackwell Publishing, Oxford, 2008) 113 at 113.

146 Lola Ianovski "Should Recovery Practices Within Mental Health Services Be Monitored? If so, How Can Organisation Recovery Orientation be Measured? A Qualitative Inquiry", above n 144, at 2.

147 Interpretation Act 1999, s 6. 
where appropriate, a court may recognise changes in the meaning of statutory concepts, ${ }^{148}$ though only where the change fits within the wording and purpose of the Act. ${ }^{149}$ That is, where the change fits within the general 'concept' of the Act. ${ }^{150}$

The wording in the statute in question must therefore be flexible enough to encompass any change in meaning. The meaning of flexible or "mobile" expressions ${ }^{151}$ such as "indecent" ${ }^{152}$ may be updated because they encompass a subjective standard which reflects contemporary circumstances. ${ }^{153}$ Whether an expression can be treated as "mobile" depends on the text and purpose of the Act. ${ }^{154}$ If the 'concept' of the Act treats the expression as determinate, to accept any changes in meaning would arguably be changing the law. ${ }^{155}$

The line between "mobile" and determinate expressions is not entirely clear. ${ }^{156}$ The English courts have taken a more expansive approach than New Zealand courts have in finding "mobility". The courts have found that the meaning of "family" has changed ${ }^{157}$ despite the fact that the legislature would have originally intended for the expression to have a determinate meaning. ${ }^{158}$ The House of Lords held in Fitzpatrick $v$ Sterling Housing Ltd, that "family" included a flexible element and would thus include a gay partner. ${ }^{159}$ This more expansive approach might be explained by the fact that "family" was held to be "mobile" to fulfil the purpose of the Act in question. ${ }^{160}$ It is unclear

148 Mark T Bradley "The Ambulatory Approach at the Bottom of the Cliff: Can the Courts Correct Parliament's Failure to Update Legislation?" (2003) 9 Canta L Rev 1 at $1 ; R$ (on the application of Quintavalle) $v$ Secretary State for Health [2003] UKHL 13, [2003] 2 AC 687 at [25].

149 J Burrows and R Carter Statute Law in New Zealand, above n 83, at 398.

150 Birmingham City Council v Oakley [2001] 1 AC 617 (HL) per Lord Hoffman.

151 Director of Public Prosecutions v Jordan [1977] AC 699 (HL) at 719.

152 R v Dunn [1973] 2 NZLR 481 (CA).

153 Mark T Bradley "The Ambulatory Approach at the Bottom of the Cliff: Can the Courts Correct Parliament's Failure to Update Legislation?", above n 148, at 23.

154 Ibid at 24.

155 Ibid at 25.

156 J Burrows and R Carter Statute Law in New Zealand, above n 83, at 392.

157 Fitzpatrick v Sterling Housing Association Ltd [2001] 1 AC 27 (HL); Dyson Holdings Ltd v Fox [1976] QB 503 (CA) although the approach taken in this latter case has since been criticised because it held that "family" had changed its linguistic meaning. See for example, Helby $v$ Rafferty [1979] 1 WLR 13 at 25 (EWCA) and $A v R$ (1999) 17 FRNZ 647 (HC).

158 J Burrows and R Carter Statute Law in New Zealand, above n 83, at 393.

159 Fitzpatrick $v$ Sterling Housing Ltd, above n 157.

160 Mark T Bradley "The Ambulatory Approach at the Bottom of the Cliff: Can the Courts Correct Parliament's Failure to Update Legislation?", above n 148, at 28. 
whether this approach would be applied in New Zealand. In any event, a court would most likely take a cautious approach to ensure that any updated meaning accords with the 'concept' of the legislation.

The essential question at this point is: would a court consider "mental health" to be "mobile" and thus open to a wide interpretation? A first adverse factor, directly on point, is that the Royal Commission report tends to suggest that "mental health" has a fixed meaning. The Commission recommended that the operative definition should be "a condition of physical and mental soundness". 161 The report is, however, only an aid to interpretation. Rather than driving interpretation, it may help to decide whether "mental health" is "mobile" having regard to the text in light of its purpose.

Most significantly, it would be inconsistent to allow flexibility around "serious danger" but confine "mental health" to the narrow definition. The same ethical conflict may arise if consultants were not free to exercise medical judgement when applying either definition. There are no studies which show exactly how consultants view "mental health". However, given that some consultants may legitimately read "mental health" widely according to their medical judgement, it is a real probability that an ethical conflict would arise. A consultant would foreseeably be torn between their desire to protect the woman's "mental health" or well-being, and the need to obey a discordant law. Therefore the purpose of allowing flexibility in medical judgement, which maintains the stability of the abortion scheme, would support adoption of the wide meaning of "mental health".

Finally, before any conclusion may be drawn, this argument must yet be reconciled with the whole concept of the legislation, which includes the potentially competing purpose to have regard to the rights of the unborn child. Arguably, although this latter purpose favours the narrow definition, it is not entirely abrogated by the wide definition. For an abortion to be authorised, the woman must still show that continuance of pregnancy would constitute serious danger to her well-being, and thus consideration is still given to the unborn child. More importantly, however, the stability of the authorisation system resulting from allowing flexibility in medical judgement arguably justifies compromising the weight placed on protecting the unborn child. If the law created an ethical conflict for the consultants, they may refuse to engage with the authorisation system altogether.

This reasoning suggests that "mental health" should be considered "mobile" and open to a wide definition. This approach would avoid an ethical conflict which would result where consultants' wide interpretation of "mental health" does not accord with the law.

Although this argument has real merit, whether it will be upheld will largely depend on the willingness of a court to engage in purposive analysis to update the meaning of "mental health". In

161 Royal Commission on Contraception Sterilisation and Abortion Contraception, Sterilisation and Abortion in New Zealand: Report of the Royal Commission of Inquiry, above n 16, at 270. 
the face of the strong case for the narrow definition, a court would be concerned to ensure that the wide definition is within the 'concept' of the legislation.

Where the issue is one of social or political importance, ${ }^{162}$ as it is here, a court may choose to leave any change up to Parliament. ${ }^{163}$ In earlier cases involving abortion issues, the courts have also had a tendency to take a more literal, textual approach, rather than a purposive approach to updating legislation. ${ }^{164}$ That said, the courts are not always unwilling to take a purposive approach in cases involving abortion. The Court of Appeal in Right to Life took a very purposive approach, by looking at the practical implications of allowing review. ${ }^{165}$

Thus, the likelihood of this argument's success is unclear. A court may uphold it but it may also refuse to consider the ambulatory approach at all, or may look unfavourably on the argument. The court may, for example, place more emphasis on the Royal Commission's recommendation of the narrow definition, or may refuse to accept that a real ethical conflict could arise.

\section{Human rights}

The second contextual argument potentially in favour of the wide definition is that the abortion legislation should be read in conjunction with the New Zealand Bill of Rights Act 1990 and with international law. Section 6 of the Bill of Rights Act directs the courts to prefer a meaning consistent with the Bill of Rights Act. International law is gaining relevance through the common law presumption that Parliament does not intend to legislate contrary to international law. ${ }^{166}$

The wide definition of "mental health" may be supported if a woman has a right to access abortion under the Bill of Rights Act or international law, and the legislation can be read consistently with that right. ${ }^{167}$

(a) New Zealand Bill of Rights Act 1990

162 J Burrows and R Carter Statute Law in New Zealand, above n 83, at 402; P v K [2003] 2 NZLR 787 (HC) at [204]-[205] per Heath J.

$163 P \vee K$, ibid.

164 See Royal College of Nursing v Department of Health and Social Security [1981] AC 800 (HL) at 822. Similarly, in Re a case stated by the Abortion Supervisory Committee [2003] 3 NZLR 87 (HC) the Court took a more textual approach to interpretation.

165 The Abortion Supervisory Committee v Right to Life New Zealand Inc, above n 8, at [100]-[109].

166 See Zaoui v Attorney-General (No 2), above n 124; Claudia Geiringer "International Law through the Lens of Zaoui: Where is New Zealand At?" (2006) 17 Public Law Review 300 at 321-322.

167 The effect of a right to life of the foetus on interpretation is not considered because the decisions of Miller J in Right to Life New Zealand Inc $v$ The Abortion Supervisory Committee and the Court of Appeal in The Abortion Supervisory Committee $v$ Right to Life New Zealand Inc strongly suggest that the foetus does not have a right to life. 
The Bill of Rights Act does not appear to guarantee a right to access abortion. Rights potentially engaged by restriction of abortion include the rights to life, ${ }^{168}$ freedom from torture, ${ }^{169}$ and nondiscrimination. ${ }^{170}$ The first two of these would not, however, support an argument in favour of the wide definition of mental health. Failing to protect full mental wellbeing would not endanger life or amount to treatment "so excessive as to outrage standards of decency". ${ }^{171}$

The question of whether a court would accept that the right to be free from discrimination under the Bill of Rights Act ${ }^{172}$ supports adopting the wide definition of mental health deserves more space than this article allows. ${ }^{173}$ It is worth noting, however, a few reasons why it may be difficult to establish that the narrow definition of mental health would be inconsistent with this right. This right prohibits discrimination on a number of specified grounds, including sex. ${ }^{174}$ Arguably it is sex discrimination to refuse a woman access to abortion because pregnancy and childbirth, which can have a potentially adverse impact on a woman's wellbeing, is unique to women.

Recent case law suggests that, in order to show that there has been discrimination, it may be necessary to establish the effect of treatment on a comparator. ${ }^{175} \mathrm{~A}$ comparator is someone who is in comparable circumstances to the complainant but without the characteristic which is the purported ground for discrimination. ${ }^{176}$ This causes a problem in the abortion context because there is no comparable pregnant male. Case law is, however, inconsistent on the need for a comparator. ${ }^{177}$

168 Section 8.

169 Section 9.

170 Section 19.

171 See Taunoa v Attorney-General [2007] NZSC 70, [2008] 1 NZLR 429; Puli'uvea v Removal Review Authority [1996] 3 NZLR 538 (CA).

172 Section 19.

173 To answer this question in full would require further discussion of whether the narrow definition of mental health is inconsistent with the right to be free from discrimination. The court may find that the narrow definition of mental health is a justified limitation in a free and democratic society, under $\mathrm{s} 5$, or that in light of the purpose of the Act, the wide definition is not a meaning that can reasonably be given to the mental health exception, as required under s 6. For authority on interpretation of the New Zealand Bill of Rights Act 1990 see $R v$ Hansen [2007] NZSC 7, [2007] 3 NZLR 1; Claudia Geiringer "Shaping the Interpretation of Statutes: Where Are We Now in the Section 6 Debate", above $\mathrm{n} 84$, for more discussion of the test in $R v$ Hansen.

174 New Zealand Bill of Rights Act, s 19. The prohibited grounds for discrimination are found in s 21(1) of the Human Rights Act 1993.

175 Ministry of Health v Atkinson HC Auckland CIV-2010-404-000287, 17 December 2010; Air New Zealand v McAlister [2008] NZCA 264, [2008] 3 NZLR 794.

176 Air New Zealand $v$ McAlister, ibid at [52] per Tipping J.

177 For example in Smith $v$ Air New Zealand [2011] NZCA 20, [2011] 2 NZLR 171 the Court did not strictly use the comparator exercise. See also Quilter v Attorney-General [1998] 1 NZLR 523 (CA). 
It may be enough to show that there has been differential treatment on a prohibited ground. This might still be difficult to establish because the differential treatment here is arguably because of society's will to protect the unborn child, not because of the woman's pregnancy or sex per se.

Further, a court may generally be reluctant to engage this right in the abortion context, because it involves policy issues. In Quilter $v$ Attorney-General, Keith J suggested that the right to nondiscrimination may not apply where the law in question involves "social values and policy". ${ }^{178}$ Finally, the Interim Select Committee report on the Bill of Rights Act suggests that the Bill of Rights Act was not intended to apply to abortion legislation. It stated that "the Bill must remain neutral on contentious issues such as abortion". ${ }^{179}$ Thus, this statement, in light of the other hurdles, suggests that the Bill of Rights Act would not support the wide definition.

(b) International law

There is a plethora of academic literature arguing that a range of rights at international law include a right to access abortion. ${ }^{180}$ Few of these arguments have, however, been accepted at international law. A number of the rights used to argue for access to abortion either do not include a right to access abortion at all ${ }^{181}$ or provide such a right only in limited circumstances. ${ }^{182}$

At international law, access to abortion is most widely addressed under the right to health. This is found in both the International Covenant on Economic, Social and Cultural Rights ${ }^{183}$ and the

178 Quilter $v$ Attorney-General, ibid at 526. This case considers the impact of non-discrimination on the exclusion of same-sex couples from the institution of marriage.

179 Interim Report of the Justice and Law Reform Select Committee: Inquiry into the White Paper, a Bill of Rights for New Zealand (Government Printer, 1986) at 53. Note this comment was made in the context of whether the right to life in s 8 of the New Zealand Bill of Rights Act should apply to a foetus.

180 For an overview, see R Cook and B Dickens "Human Rights Dynamic of Abortion Law Reform" (2003) 25 HRQ 1; and JM Gher and C Zampas "Abortion as a Human Right: International and Regional Standards" (2008) 8 HRLR 249.

181 For example, the powerful right of "liberty and security" has been used in both the United States in Roe $v$ Wade 410 US 113 (1973) and Canada in $R v$ Morgentaler [1993] 1 SCR 462 to guarantee a constitutional right to abortion. Although this right is found in art 9(1) of the International Convention on Civil and Political Rights, it has not been interpreted to include a right to abortion. See Daniel Fenwick "Recognition of violations of women's human rights under the European Convention on Human Rights in the context of restrictive abortion regimes" (Masters Thesis, Durham University, 2011).

182 For example, the right to be free from cruel and degrading treatment was interpreted to include a right to abortion in limited circumstances in Karen Noelia Llantoy Huamán v Peru, ICCPR/C/85/D/1153/2003 (2005). The woman was denied an abortion after discovering that the foetus had an anencephaly. See JM Gher and C Zampas "Abortion as a Human Right: International and Regional Standards", above n 180, at 269-272.

183 International Convention on Economic Social and Cultural Rights 993 UNTS 3 (opened for signature 16 December 1966, entered into force 3 January 1976). Art 12(1) guarantees that everyone has the right to 
Convention on the Elimination of all Forms of Discrimination against Women (CEDAW). ${ }^{184}$ The precise scope of the right to health is unclear, ${ }^{185}$ but broadly it is said to encompass underlying preconditions for health, and healthcare which is available, accessible, acceptable, and of adequate quality. ${ }^{186}$

There is no precise definition at the international level of what the right to health guarantees in the abortion context. ${ }^{187}$ It has not been directly enforced in the abortion context by any international body. ${ }^{188}$ The right to health can arguably be interpreted as requiring governments to remove legal restrictions on abortion both to avoid the risks of unsafe abortion and to guarantee access to abortion where a woman's health is at risk. ${ }^{189}$

The main concern among international policy and treaty-monitoring bodies is preventing the risks of unsafe abortion. The preferred solution is prevention of unwanted pregnancy, rather than removing legal restrictions on abortion. For example, the 1995 Report on the Fourth World Conference on Women acknowledged that unsafe abortion is a major public health concern, ${ }^{190}$ but focused on improving family planning methods and promoting regulation of fertility that is not against the law. ${ }^{191}$

The CEDAW Committee has continually expressed concern about unsafe abortion in its Concluding Observations to State parties, and often focuses on improving family planning methods. ${ }^{192}$ It has never expressly acknowledged that safe, legal abortion is always needed where

"enjoyment of the highest attainable standard of physical and mental health". (Ratified by New Zealand on 28 December 1978).

184 Convention on the Elimination of All Forms of Discrimination against Women 1249 UNTS 13 (opened for signature 21 December 1965, entered into force 4 January 1969), art 12(1). (Ratified by New Zealand on 10 January 1985). This also expressly includes the right to reproductive healthcare.

185 Ronli Sifris "Restrictive Regulation of Abortion and the Right to Health" (2010) 18 Medical Law Review 185 at 192.

186 World Health Organisation "The Right to Health: Fact Sheet No 323" (2007) <www.who.int>; Ronli Sifris "Restrictive Regulation of Abortion and the Right to Health", ibid at 192.

187 JM Gher and C Zampas "Abortion as a Human Right: International and Regional Standards", above n 180, at 268.

188 Ibid.

189 Ibid.

190 United Nations Department for Policy Coordination and Sustainable Development Report of the Fourth World Conference on Women A/CONF 177/20 1995) at [97]. For more discussion of this report, see Ronli Sifris "Restrictive Regulation of Abortion and the Right to Health", above n 185.

191 Ibid.

192 JM Gher and C Zampas "Abortion as a Human Right: International and Regional Standards", above n 180, at 272 . 
contraception fails. ${ }^{193}$ The Committee has, however, recognised that criminalisation of abortion is a barrier to appropriate healthcare. ${ }^{194}$ The Committee has also continually recognised the link between restrictive abortion laws and unsafe abortion in its Concluding Observations. ${ }^{195}$

The wide definition of mental health would be more consistent with the right to health than the narrow definition because the wide definition provides greater access to legal abortion and thus protects more women against unsafe abortion. Limiting "mental health" to the narrow definition may restrict access to legal abortion. ${ }^{196}$ The ASC has noted the connection between restricting legal access and unsafe abortion. In 1986, the Committee noted that restrictive abortion laws create unsafe abortion for those unable to travel to Australia. ${ }^{197}$ In 1997, the Committee stated: "If we do not have legal abortion we will have illegal abortion and maternal deaths. Making abortion illegal does not stop it". 198

Research supports this connection between legality and unsafe abortion. If women are denied legal abortion, they will seek abortion elsewhere, even if it is unsafe. A study in the Czech Republic showed that women who are denied an abortion go to great lengths to find one elsewhere. ${ }^{199}$ Empirical evidence from Romania shows that the maternal mortality rate is directly affected by the restriction or liberalisation of abortion law. After restriction of abortion law in 1966, the mortality ratio rose from 20 per 100,000 live births to 148 per 100,000 in 1989. After liberalisation in 1989, the rate fell and in 2002 was at nine per 100,000. ${ }^{200}$

193 Ibid.

194 General Recommendation 24: Women and Health HRI/GEN/1/Rev.5 (2001) at [14].

195 See JM Gher and C Zampas "Abortion as a Human Right: International and Regional Standards", above n 180, at 272-273 and Center for Reproductive Rights "Briefing Paper: Abortion and Human Rights" (2008) $<$ reproductiverights.org>. For example, it has expressed concern about the lack of protection for women's reproductive health in Chile due to the effect of restrictive abortion laws on access to safe abortion in Committee on the Elimination of Discrimination against Women Concluding Observations of the Committee on the Elimination of Discrimination Against Women CEDAW/C/CHI/CO/ 4 (2006).

196 This argument is based on the assumption that adoption of the narrow definition would affect current medical practice. See discussion in this article above at Part IV highlighting that no conclusive conclusion can be drawn about whether doctors are currently authorising abortion for something less than a real risk of recognised mental illness.

197 Report of the Abortion Supervisory Committee (1986). Prior to liberalisation of abortion law in 1977, many women travelled to Australia to obtain abortion. See Margaret Sparrow Abortion Then \& Now: New Zealand Abortion Stories from 1940 to 1980, above n 17, at 203-204.

198 Report of the Abortion Supervisory Committee (1997).

199 H David, Z Dytrych and Z Matejcek "Born Unwanted: Observations for the Prague Study" (2003) 58 American Psychologist 224.

200 David A Grimes and others "Unsafe Abortion: The Preventable Pandemic" (2006) 368 Lancet 1908 at 1917. 
Thus, the wide definition may be more consistent with the right to health because this definition avoids the risks of unsafe abortion. For this argument to be accepted, it must be shown that the courts would be willing to enforce the right to health. International law is not directly enforceable unless incorporated into domestic law. ${ }^{201}$ There is, however, a common law presumption that Parliament does not intend to legislate contrary to human rights. ${ }^{202}$ Traditionally, the approach to this presumption has been: where possible, the wording will be read consistently with international law, but this must accord with the purpose of the Act. ${ }^{203}$ On this approach, the right to health may not be enough to support the wide definition of mental health because the definition may undermine the purpose of the abortion legislation to have regard to the rights of the unborn child.

The presumption of consistency has, however, been gaining strength, and arguably, at its most extreme, can override the purpose of the Act, as seen in the Supreme Court's rigorous approach in Zaoui v Attorney-General (No 2). ${ }^{204}$ In that case, the Court held that a statute conferring an administrative power to deport Mr Zaoui had to be interpreted consistently with his right, at international law and under the New Zealand Bill of Rights Act, to be free from torture. ${ }^{205}$ The Court came to this conclusion despite indications in the wider statutory scheme that Parliament intended otherwise, ${ }^{206}$ and that this arguably went beyond the statutory purpose. ${ }^{207}$

The approach seen in Zaoui suggests that where the "underlying international obligation is sufficiently compelling, nothing less than express statutory language may suffice to overcome it". 208 Two factors underpin the Court's assessment in Zaoui of the obligation as sufficiently compelling, which indicate the scope of this rigorous approach. First, the judiciary has historically been more willing to enforce civil and political rights, such as the right to freedom from torture, than to enforce social rights like the right to health. Secondly, the Court took a strict and conservative approach to defining the scope of the obligation in question. ${ }^{209}$

201 See Tavita v Minister of Immigration and Attorney-General [1994] 2 NZLR 257 (CA).

202 See Zaoui v Attorney-General (No 2), above n 124.

203 J Burrows and R Carter Statute Law in New Zealand, above n 83, at 32.

204 Zaoui v Attorney-General (No 2), above n 124.

205 Claudia Geiringer "International Law through the Lens of Zaoui: Where is New Zealand At?", above n 166, at $321-322$.

206 Claudia Geiringer "Zaoui Revisited" [2005] NZLJ 285 at 288.

207 Claudia Geiringer "Principle of Legality and the Bill of Rights Act: A Critical Examination of $R v$ Hansen" (2008) 6 NZJPIL 59 at 91.

208 Claudia Geiringer "International Law through the Lens of Zaoui: Where is New Zealand At?", above n 166, at 317.

209 Ibid at 314. 
Because of the social nature of the right to health, a court is likely to be more reluctant to enforce it than to enforce the right to freedom from torture, as in Zaoui. Out of respect for parliamentary sovereignty, the courts are reluctant to apply social rights which are more policybased, and therefore better suited to statutory implementation. ${ }^{210}$ The High Court has, for example, rejected an argument that a rent increase forcing the complainant to move was a breach of the right to an adequate standard of living. ${ }^{211}$ The Court of Appeal has similarly refused to use international law to interpret a statutory right to education. ${ }^{212}$

The judiciary would also be reluctant to uphold such rights in light of a clear intention behind the Bill of Rights Act not to allow the judiciary to uphold social rights. The Bill which later became the Bill of Rights Act excluded economic, social and cultural rights to avoid an "attempt to capture (or more accurately to impose) a temporarily popular view of policy". ${ }^{213}$ The Interim Select Committee report on the Bill of Rights noted that it would be inappropriate for the judiciary to make "essentially political" decisions concerning questions of whether legislation "provides an adequate standard of health care or affects the right to an adequate standard of living".214

Even if the right to health were considered justiciable, there are other reasons why the presumption of consistency is unlikely to be applied as robustly as it was in Zaoui. ${ }^{215}$ The very cautious approach taken to defining the scope of the international obligation in Zaoui limits the situations in which the presumption will apply. ${ }^{216}$ In Zaoui the international obligation was defined even more narrowly than expressly recognised at international law. ${ }^{217}$ In contrast, the scope of the right to health is still murky. It is not clear at international law that this right includes the right to access abortion.

210 Claudia Geiringer "Parsing Sir Kenneth Keith's Taxonomy of Human Rights: A Commentary on Illingworth and Evans Case" in Rick Bigwood (ed) Public Interest Litigation: New Zealand Experience in International Perspective (Lexis Nexis, Wellington, 2006) 179 at 180.

211 Lawson v Housing New Zealand [1997] 2 NZLR 474 (HC) at [39]. Williams J held: "Whether New Zealand has fulfilled its international obligations is a matter on which it may be judged in international forums but not in this Court".

212 Attorney-General v Daniels [2003] 2 NZLR 742 (CA).

213 A Bill of Rights for New Zealand: A White Paper (Department of Justice A6, 1985) at 3.14.

214 Interim Report of the Justice and Law Reform Select Committee: Inquiry into the White Paper, a Bill of Rights for New Zealand, above n 179, at 79.

215 Claudia Geiringer "International Law through the Lens of Zaoui: Where is New Zealand At?", above n 166, at 318 .

216 Ibid at 318.

217 Ibid at 312. 
Further, the willingness of a court to apply the presumption of consistency will depend on the context of the domestic statute. ${ }^{218}$ Factors which influence the courts' approach to a breach of human rights include the rule in question, the nature of the breach, the forcefulness with which the countervailing purpose has been expressed, and legislative history. ${ }^{219}$ The breach in question here, that is, the general possibility of unsafe abortion is much less specific than a clear risk of torture of an individual, as in Zaoui. ${ }^{220}$ Further, the argument for an interpretation consistent with the right to health must be considered in the context of the strong argument in favour of the narrow definition arising from the abortion legislation and its legislative history. In conclusion, a court would no doubt refuse to uphold an argument based on the right to health in support of the wide definition of mental health.

This wide-ranging discussion suggests that human rights law has much to say in the area of abortion. The sensitive nature however prevents this argument from moving from the theoretical to the practical and thus does not provide any tenable argument for the wide definition of mental health.

In summary of the arguments in favour of each definition, the narrow definition of mental health finds strong support in the argument that this will uphold the purpose of the abortion legislation to have regard to the rights of the unborn child. There is, however, a competing and potentially stronger argument in favour of the wide definition of mental health. That is, "mental health" should be interpreted widely to ensure that consultants can freely exercise medical judgement, a condition on which the stability of the abortion system is based. It is unclear whether this argument will prevail - it predominantly rests on the willingness of a court to engage in a purposive ambulatory analysis in the controversial context of abortion.

\section{The Meaning of "Serious Danger ... to ... Mental Health" as a Whole}

Finally, the definition of "mental health" must be planted into the whole phrase of "serious danger to ... mental health" to be considered as a whole. Although the meaning of "serious danger" would be flexible according to the need to allow consultants to freely exercise their medical judgement, there is some guidance from case law. In $R v$ Woolnough, shortly before enactment of

218 Application depends on "both the international text and the related national statute". See New Zealand Air Line Pilots' Association v Attorney-General [1997] 3 NZLR 269 (CA) in Claudia Geiringer "International Law through the Lens of Zaoui: Where is New Zealand At?", ibid at 318.

219 Claudia Geiringer "Parsing Sir Kenneth Keith's Taxonomy of Human Rights: A Commentary on Illingworth and Evans Case", above n 210, at 90; also referring to Janet McLean "Legislative Invalidation, Human Rights Protection and s 4 of the New Zealand Bill of Rights Act" [2001] NZ Law Rev 421. These factors are discussed with a particular emphasis on their relevance to the application of s 6 of the New Zealand Bill of Rights Act 1990.

220 Zaoui v Attorney-General (No 2), above n 124. 
the abortion legislation, the Court found that "serious danger" means "a real and substantial risk of serious harm". 221

If a court adopts the wide definition of mental health, "serious danger ... to ... mental health" would most likely cover current practice, even if it proves correct that consultants are liberally applying the law. Continuance of pregnancy would create a "serious danger" if it poses a real and substantial risk of serious harm to the woman's wellbeing. Ultimately this is a clinical judgement, but it seems that this would be met in a range of common situations. ${ }^{22}$ Pregnancy might negatively impact a woman's wellbeing, for example, by putting pressure on her financial situation or her relationships. This would allow for the liberal application, which Miller J suspected consultants were taking.

If a court adopts the narrow definition of "mental health", "serious danger ... to ... mental health" may set a higher threshold than under the wide definition, but it still arguably allows consultants slightly more flexibility than Miller J assumed. "Serious danger ... to ... mental health" will be met if continuance of pregnancy would create a real and substantial risk of serious harm to the woman's state of being free from mental illness. Because this is a clinical judgement, it is not the court's place to decide what constitutes the necessary harm. ${ }^{223}$

In practice, consultants would presumably assess whether there is risk of mental illness. Some consultants might look to whether there is risk of the woman developing a recognised psychiatric illness, such as an illness found in the Diagnostic and Statistical Manual of Mental Disorders. ${ }^{224}$ There is no reason why consultants must, however, strictly rest authorisation on a recognised diagnosis, as Miller $\mathrm{J}$ suggested. ${ }^{225}$ This would go against common practice. Research shows that general practitioners do not often use diagnostic schema in assessing mental illness, ${ }^{226}$ because they are generally perceived as too rigid and complex. ${ }^{227}$ Thus "serious harm" may be met by something less than a recognised diagnosis, so long as the consultant believes it to be such, in good faith. ${ }^{228}$

$221 R v$ Woolnough, above $\mathrm{n} 14$, at 521 per Woodhouse $\mathrm{J}$.

222 Wall v Livingston, above n 37; Right to Life New Zealand Inc v The Abortion Supervisory Committee, above $\mathrm{n} 2$; The Abortion Supervisory Committee v Right to Life New Zealand Inc, above n 8.

223 Ibid.

224 American Psychiatric Association Diagnostic and Statistical Manual of Mental Disorders DSM-IV-TR (4th ed, American Psychiatric Association, Washington DC, 2000).

225 Right to Life New Zealand Inc v The Abortion Supervisory Committee, above n 2. An example of a recognised diagnosis which Miller J had in mind was "major depressive disorder".

226 Steven Lillis, Graham Melsop and Gaelle Dutu "General Practitioners' View on the Major Psychiatric Classification Systems" (2008) 121 Journal of the New Zealand Medical Association 3373.

227 Ibid.

228 In accordance with s 40 of the Contraception, Sterilisation, and Abortion Act. 
Further, if the negative definition were adopted, consultants would be free to take into account a range of factors in assessing risk, including foreseeable social and economic circumstances, both during pregnancy and if the child were born. Miller $\mathrm{J}$ in Right to Life recognised this, in noting that consultants may consider socio-economic consequences of raising a child in assessing risk of recognised mental illness. ${ }^{229}$

The application of the mental health exception in New South Wales provides an example of such a risk assessment. In New South Wales, the mental health exception is a judicial, rather than statutory creation. ${ }^{230}$ In 1972, in $R v$ Wald the New South Wales District Court ${ }^{231}$ interpreted "serious danger to mental health" as including serious danger arising out of economic, social or medical reasons at any time during the currency of the pregnancy. ${ }^{232}$ This test was applied and extended in CES $v$ Superclinics, where Kirby ACJ held that the test would also include danger which might arise after the birth of the child. ${ }^{233}$ That case concerned a 21-year-old student in an unstable relationship with limited financial means. His Honour held that the test would clearly be met having regard to the foreseeable effects of an unwanted pregnancy in the context of an unstable relationship, and of having to give up her studies and thereby her opportunity for fulltime employment in her chosen field. ${ }^{234}$

The abortion legislation supports this approach to risk assessment. This approach allows consultants flexibility in medical judgement, but still has regard to the rights of the unborn child because the factors considered must still amount to risk of "serious harm". The indication in the legislation that sexual violation and extremes of age may be taken into account in assessing "serious danger" does not mean that other factors may not also be taken into account. ${ }^{235}$ The Royal Commission explicitly recognised that, depending on the woman's personal reaction, socioeconomic factors may result in serious danger to mental health. ${ }^{236}$ Thus, even where a court adopts the narrow definition of mental health, consultants will have significant flexibility to take into

229 Right to Life New Zealand Inc v The Abortion Supervisory Committee, above n 2, at [54]. Miller J noted that "some women who seek an abortion, perhaps lacking the resources or family support to raise a child, may risk major depressive disorder if the pregnancy continues".

230 Like in New Zealand, the legal test for abortion in New South Wales stems from the English case of $R v$ Bourne, above n 14. See $R v$ Wald (1971) 3 DCR 25 (NSW).

231 Then called the Quarter Sessions.

$232 R v$ Wald, above n 230.

233 CES v Superclinics (Australia) Pty Ltd (1995) 38 NSWLR 47 (NSWSC).

234 At 65.

235 Nicola Peart "Prevention and Termination of Life before Birth", above n 13, at 488.

236 Royal Commission on Contraception Sterilisation and Abortion Contraception, Sterilisation and Abortion in New Zealand: Report of the Royal Commission of Inquiry, above n 16, at 272. 
account all factors which might amount to real risk of mental illness, according to their own judgement.

\section{CONCLUSION}

In conclusion, even if, as Miller $\mathrm{J}$ suspected, consultants are authorising abortion under the mental health exception for something less than risk of a recognised diagnosis of mental illness, the courts may yet uphold this approach as a lawful application of the mental health exception.

There is a strong argument that the wide definition of mental health should be accepted to preserve the stability of the abortion scheme. Allowing the wide definition would accord with medical judgement and thus avoid any ethical conflict between medical judgement and the law. As suggested, a court may, however, be reluctant to engage in a purposive ambulatory interpretation and may thus prefer to adopt the narrow definition.

Nevertheless, even if a court upholds the narrow definition, consultants still have substantial flexibility in exercising medical judgement about what constitutes "serious danger to ... mental health". Accordingly, preference for the narrow definition may not render current practice as vulnerable to challenge as would acceptance of Miller J's assumption that authorisation must rest on a recognised diagnosis.

In light of the limited opportunities for the interpretation of the mental health exception to arise in the courts, current practice may, however, simply go on untested. Nonetheless, the legal uncertainty around the meaning of the mental health exception and around whether there is a discrepancy between the practice and the law is undesirable. According to Joseph Raz, the rule of law requires that "the law should be such that people will be able to be guided by it". ${ }^{237}$ Parliament should thus intervene to ensure that the law is certain.

Given the highly controversial nature of abortion, it seems unlikely, however, that Parliament will be willing to engage with the issue. No doubt willingness to intervene would be influenced by its perception of the urgency of the issue. It would only make sense for Parliament to engage with this issue if current practice, which seems to avoid the risks of unsafe abortion, was under direct threat. Perhaps the necessary threat would arise if the Supreme Court overturns the Court of Appeal finding in Right to Life to find that the ASC can review abortion authorisations. In the meantime, however, New Zealand may simply have to continue to accept the uncertain relationship between the practice and the law.

237 Joseph Raz The Authority of Law: Essays on Law and Morality (Oxford University Press, Oxford, 1983) at 213. 